\title{
Скронево-нижньощелепний суглоб: анатомічні та функціональні особливості в віковому аспекті, етіологія і поширеність захворювань серед спортсменів
}

\author{
УдК 796.056«4»:616.724+611+616-02
}

\section{В. А. Пастухова, Г. В. Лук'янцева, С. П. Краснова, Ю. М. Порадун, О. С. Чуприна}

Національний університет фізичного виховання і спорту України, Київ, Україна

\begin{abstract}
Резюме. У статті наведено сучасні погляди на будову, функції, частоту виникнення, практичне значення і лікування запальних і дегенеративних захворювань скроневонижньощелепного суглоба (СНЩС). На прикладі проведених досліджень показано, що ці хвороби можуть виступати як складова артритичного синдрому при псоріатичному, ревматоїдному, інфекційних артритах, анкілозивному спондилоартриті та остеоартриті. Аналіз опрацьованих джерел дозволив дійти висновку, що кожний випадок будь-яких порушень або захворювань СНЩС потребує обов'язкової оцінки артритичного статусу, оклюзії та проведення об'єктивного обстеження з метою виявлення структурних змін. Описано особливості захворювань скронево-нижньощелепного суглоба в віковому аспекті. Наведено дані щодо частоти порушень у компонентах скронево-нижньощелепного суглоба спортсменів на прикладі легкоатлетів. Зроблено акцент на важливості визначення етіології і патогенезу захворювань суглоба в кожному окремому випадку, продемонстровано дані щодо частоти ураження скронево-нижньощелепного суглоба у спортсменів, надано практичні рекомендації. Ключові слова: скронево-нижньощелепний суглоб, будова, функція, етіологія, патогенез, поширеність, спортсмени.
\end{abstract}

Височно-нижнечелюстной сустав: анатомические и функциональные особенности в возрастном аспекте, этиология и распространенность заболеваний среди спортсменов

В. А. Пастухова, Г. В. Лукьянцева, С. П. Краснова, Ю. М. Порадун, О. С. Чуприна

Национальный университет физического воспитания и спорта Украины, Киев, Украина

Резюме. В статье приведены современные взгляды на строение, функции, частоту возникновения, практическое значение и лечение воспалительных и дегенеративных заболеваний височно-нижнечелюстного сустава (ВНЧС). На примере проведенных исследований показано, что эти болезни могут являться составляющей артритического синдрома при псориатическом, ревматоидном, инфекционных артритах, анкилозирующем спондилите и остеоартрите. Анализ источников литературы показал, что каждый случай каких-либо нарушений или заболеваний ВНЧС требует обязательной оценки артритического статуса, окклюзии и проведения объективного обследования с целью выявления структурных изменений. Описаны особенности заболеваний височно-нижнечелюстного сустава в возрастном аспекте. Приведены данные о частоте нарушений в компонентах височнонижнечелюстного сустава спортсменов на примере легкоатлетов. Сделан акцент на важности определения этиологии и патогенеза заболеваний сустава в каждом отдельном случае, продемонстрированы данные о частоте поражения височно-нижнечелюстного сустава у спортсменов, даны практические рекомендации.

Ключевые слова: височно-нижнечелюстной сустав, строение, функция, этиология, патогенез, распространенность, спортсмены. 
Temporomandibular joint: anatomical and functional features in age aspect, etiology and prevalence of diseases among athletes

\title{
V. A. Pastukhova, H. V. Lukiantseva, S. P. Krasnova, I. M. Poradun, O. S. Chupryna
}

National University of Physical Education and Sport of Ukraine, Kyiv, Ukraine

\begin{abstract}
The article presents the modern views on the structure, functions, frequency of occurrence, practical significance and treatment of inflammatory and degenerative diseases of the temporomandibular joint (TMJ). Studies have shown that these diseases can have a course as a component of arthritic syndrome in psoriatic, rheumatoid, infectious arthritis, ankylosing spondylitis and osteoarthritis. The analysis of sources allowed to conclude that every case of any disorders or diseases of the TMJ requires the necessary assessment of arthritic status, occlusion and an objective examination in order to detect structural changes. The features of diseases of the temporomandibular joint in age aspect are described. The data on the frequency of disorders in the components of the temporomandibular joint of track and field athletes are presented. Emphasis is placed on the importance of determining the etiology and pathogenesis of joint diseases in each individual case, the data on the frequency of lesions of the temporomandibular joint in athletes are demonstrated, and practical recommendations are given. Keywords: temporomandibular joint, structure, function, etiology, pathogenesis, prevalence, athletes.
\end{abstract}

Постановка проблеми. Значна поширеність захворювань скронево-нижньощелепного суглоба (СНЩС), надзвичайний поліморфрізм їх клінічних проявів, труднощі діагностики та лікування, суперечливість у поглядах авторів щодо питань функціональних порушень суглоба при різних видах його нестабільності та їх корекції ставлять цю патологію у ряд важливих медичних $\mathrm{i}$ соціальних проблем сучасності. За даними літератури, у дітей і підлітків у міру дорослішання частота і поширеність патології СНЩС збільшуються [7, 20]. Під час тренувань у спортсменів задіяний весь комплекс опорно-рухового апарату, зокрема і СНЩС, проте проблема функціональних порушень у ньому недостатньо висвітлена. Захворювання СНЩС можуть виступати як пускові і підтримуючі фрактори у розвитку системної патології. У свою чергу, системні порушення накладають відбиток на клінічні прояви, перебіг, результат і прогноз захворювань СНЩС.

Мета дослідження - узагальнення даних літератури щодо вікових особливостей будови та функції, етіології і поширеності захворювань скронево-нижньощелепного суглоба серед спортсменів, зокрема легкоатлетів.

За своєю будовою і характером рухів скронево-нижньощелепний суглоб $є$ одним із найскладніших з'єднань у організмі людини. 3 моменту початку формування зубних рядів і до глибокої старості СНЩС зазнає значних змін. Будова СНЩС має багато спільних рис з іншими суглобами. Водночас, будучи одним з понад 230 суглобів людини, він характеризується і деякими морфосрункціональними особливостями, властивими саме цьому анатомічному утворенню $[33,36]$.

Головною особливістю будови СНЩС $\epsilon$ наявність внутрішньосуглобових зв'язок, розташо- ваних між кістковими суглобовими поверхнями і суглобовим диском, який розділяє суглоб на два відділи (поверхи).

Верхня частина суглобової ямки не має хряща. Хрящ покриває тільки дистальну частину суглобового горбка і головку виросткового відростка. За своєю будовою суглобовий диск належить до м'якотканинних утворень: він складається 3 щільної фріброзної тканини, не має судин і нервів. Товщина суглобового диска в сагітальній проекції неоднакова і поділяється на три зони: передню, середню (центральну) і задню. Середня зона найбільш тонка, задня зазвичай товща за передню. Правильне положення суглобової головки в середній зоні суглобового диска утримується за рахунок внутрішньосуглобового тиску і потовщених країв диска. Розміри суглобового диска коливаються залежно від індивідуальних особливостей [2]. На підставі даних комп'ютерної томографрії СНЩС в сагітальній проекції Е. X. Christiansen зі співавт. встановили, що в нормі ширина суглобової щілини в передньому відділі становить 1,4 мм; у верхньому - 2,2 мм; у задньому - 3,7 мм [31]. За даними В. В. Баданіна зі співавт. [1] в ході аналогічного дослідження встановлено такі параметри суглобової щілини: у передньому відділі - 1,6 $\pm 0,2$ мм; у верхньому $-1,8 \pm 0,2$ мм; у задньому $-2,0 \pm 0,3$ мм. 3 нижнью поверхнею суглобового диска стикається суглобова головка, яка здійснює обертальний рух під час відкривання рота до 2,0-2,5 см. При подальшому русі суглобова головка разом з диском рухається вперед і вниз. Таким чином забезпечується комбінований (поступальний і обертальний) рух СНЩС.

Суглобовий диск ззаду прилягає до пухкої сполучної тканини, яка добре постачається 
кров'ю і інервується. Ї̈̈ називають задисковою зоною. Зверху вона межує з верхньою задисковою пластиною, яка містить велику кількість еластичних волокон і приєднується до заднього краю диска. Нижньою межею задискової ділянки $\epsilon$ нижня задискова пластина, яка прикріплюється до нижньої межі заднього краю диска і заднього краю суглобової поверхні виросткового відростка. Нижня задискова пластина, на відміну від верхньої, містить колагенові волокна. Оскільки задискова ділянка містить дві пластини, її називають біламінарною зоною. Ззаду задискова ділянка межує із задньою зв'язкою капсули, що оточує СНЩС. У передньому відділі суглобовий диск межує з передньою зв'язкою капсули, яка містить колагенові волокна, вгорі з'єднується 3 переднім краєм суглобової поверхні скроневої кістки, а внизу - $з$ переднім краєм суглобової поверхні виросткового відростка. Між верхньою і нижньою частинами передньої зв'язки капсули в суглобовий диск вплітається сухожилок верхнього пучка латерального крилоподібного м'яза [23]. При пошкодженні і розтягненні зв'язок суглобовий диск може зміщуватися по всій поверхні виросткового відростка. Такий стан призводить спочатку до функціональних порушень, а потім до запальних і дегенеративних захворювань СНЩС [26, 38].

Амплітуду рухів нижньої щелепи регулює суглобова капсула, яка представляє собою податливу сполучнотканинну оболонку. Розтягуванню суглобової капсули перешкоджають екстракапсулярні зв'язки, утворені фіброзною сполучною тканиною. У зв'язку з такою будовою первісна довжина зв'язок не відновлюється після перерозтягнення [30].

Ю. А. Петросов зі співавт. [14] встановили, що остаточне формування кісткових елементів суглоба завершується до десяти років. Відмічається нерівномірність щільності окремих елементів суглобового диска. Вікова група 12-14 років характеризується завершеністю фоормування оптимальних анатомо-фрізіологічних відносин елементів СНЩС. У цьому віці відбувається остаточне формування переднього суглобового горбка і редукція заднього. До 16-17 років відбувається повне становлення всіх елементів суглоба. За своєю функцією суглоб є комбінованим, оскільки рух одного суглоба тягне за собою рух суглоба протилежної сторони.

Зубощелепна система функціонує в результаті складної взаємодії щелеп, жувальних м'язів, пародонта, зубів, СНЩС. Зв'язок між ними здійснюється системою трійчастого нерва з чутливими і руховими ядрами, тісно пов'язаними з кірковими і підкірковими центрами головного мозку
[29]. Важливою особливістю фрункції жування $€$ те, що нижня щелепа рухається у вертикальній, сагітальній та фронтальній площинах. Під час жування відбувається взаємодія всіх органів зубощелепної системи: СНЩС, м'язів, щелеп, пародонта та зубів.

За літературними даними $[17,25,37]$, рухи нижньої щелепи під час жування відбуваються в трьох взаємно перпендикулярних площинах. Нижня щелепа може здійснювати бічні зміщення при звичному змиканні приблизно на 10 мм, зміщення вперед приблизно на 9 мм, назад - на 1 мм, вниз - на 50 мм. Зміщення нижньої щелепи 3 положення «центрального співвідношення» у звичне змикання супроводжується рухом суглобових головок вниз і вперед по заднім поверхням суглобових горбків. Довжина цього ковзання становить близько 1 мм. За спостереженнями Minden та співавт. [35], такий рух відбувається у $90 \%$ населення. Під час відкривання рота в СНЩС відбувається складна комбінація рухів. Спочатку обидві суглобові головки здійснюють ротацію навколо фронтальної осі в нижньому поверсі суглоба, де западиною $є$ нижня поверхня внутрішньосуглобового диска. При цьому верхній полюс головки разом із диском зміщуються вентрально. Центр обертання цієї фрази рухів знаходиться на передньо-внутрішній частині суглобової головки. Подальше відкривання рота шляхом шарнірного руху суглобових головок без пошкодження тканин позаду суглобових головок неможливо. Тому починаються поступальні рухи головок вперед і вниз по задній поверхні суглобових горбків до встановлення суглобових головок на вершинах. Внутрішньосуглобовий диск змінює своє положення і починає зміщуватися вперед по задній поверхні суглобового горбка. При цьому серединна точка нижніх різців описує дугу довжиною 50 мм. У ході цієї складної комбінації рухів головка здійснює ротацію майже на $100^{\circ}$, а кут ковзання диска становить близько $40^{\circ}$. При цьому обидва СНЩС «працюють» строго координовано [8]. Частково ступінь відкривання рота обмежується тим, що внутрішньосуглобовий диск стає попереду головки нижньої щелепи. При мінімальній активності жувальної мускулатури нижня щелепа займає положення фрізіологічного спокою. При цьому міжоклюзивна висота становить 2-4 мм. Це положення нижньої щелепи наближується до звичної оклюзії. Оскільки максимальне відкривання рота - це поєднання шарнірних і поступальних рухів, і залежить воно від м'язів, положення «фізіологічного спокою» не завжди може бути відтворено неодноразово. Воно залежить від положення голови. Під час на- 
хилу голови вперед вихідне положення «фізіологічного спокою» також зміщується вперед [27].

Скронево-нижньощелепний суглоб $є$ парним і найскладнішим суглобом за своєю будовою в організмі людини, який здійснює комбінацію рухів, що складається з ковзання і обертання навколо «плаваючого центру». СНЩС не тільки складова частина зубощелепної системи, він $€$ одним із складних працюючих вузлів тіла людини $[13,40]$.

Патологія СНЩС є однією з поширених хвороб людини. Функціональні захворювання цього суглоба $є$ поширеною патологією і зустрічаються за даними ряду авторів у 27,5-39\% населення [5, 34]. За даними В. А. Сьомкіна, Н. А. Рабухіної [16], частота дисорункцій СНЩС серед дітей шкільного віку становить від 36 до $88 \%$, дисфункція СНЩС зустрічається вже у 14-20\% дітей і підлітків і значно зростає за частотою у осіб старших вікових груп. Етіологія і патогенез фрунціональних уражень СНЩС, так само, як і інших суглобів, дуже різноманітні.

Етіологія порушення фрункції СНЩС вважається мультифракторною, але відносна важливість індивідуальних етіологічних фракторів суперечлива [11]. Серед головних причин виникнення дисфункції СНЩС виділяють порушення міодинамічної рівноваги в діяльності жувальних і латеральних крилоподібних м'язів, що забезпечують переміщення суглобового диска. Причинами порушення міодинамічної рівноваги найчастіше $€$ порушення оклюзійних взаємин, обумовлених деформаціями і дефектами зубних рядів, морфрофункціональними змінами в м'язах щелепнолицевої ділянки, травмою, патологічною стертістю зубів, аномалією положення зубів, тощо [4].

Прихильники оклюзійної теорії і нейром'язової теорій погоджуються з тим, що біль при дисфункції СНЩС має головним чином м'язове походження, проте теорії розрізняються щодо причини міоспазму. C. R. Carlson зі співавт. [28] запропонували уніфріковану концепцію, згідно з якою стресові ситуації викликають напруження м'язів, виникає порушення у мозкових центрах, від яких гамма-еферентні волокна ідуть до м'язів. Кругові рухи нижньої щелепи забезпечуються жувальними м'язами і призводять до атипових рухів виростків у суглобових ямках і до дисфункції СНЩС.

Ю. А. Петросов [14] також стверджував, що у разі порушення оклюзії нейром'язові і оклюзійно-артикуляційні порушення $€$ взаємообумовленими.

За даними досліджень П. Г. Сисолятіна [18], J.J. Buescher [24] у патогенезі розвитку захворювань СНЩС головну роль відіграють три фракто- ри: порушення фрункції нейром'язового комплексу, порушення взаємини зубних рядів і елементів СНЩС, причому основне місце відводиться першому фактору. Всі вони, на думку авторів, $€$ взаємопов'язаними і взаємообумовленими.

У дослідженнях ряду авторів [15, 22] встановлено дві основні причини дисфункції СНЩС: місцеві (руйнування зубів різної етіології, деформації та дефекти зубних рядів, порушення в м'язах щелепно-лицевої ділянки, травма щелепно-лицевої ділянки) і загальні (психоемоційні зміни, що призводять до дискоординації рефлексів зубощелепної системи, порушення метаболізму гормонів, ендокринні захворювання, порушення обміну речовин).

Крім порушень оклюзії і стресових навантажень в етіології дисфункції СНЩС значне місце відводять травмі: одномоментній мікротравмі, хронічній мікротравмі. В одних випадках це забої, удари, складні видалення зубів, широке позіхання, ускладнення реконструктивних операцій, родова травма та ін. В інших - хронічне мікротравмування суглобових елементів, пов'язане 3 оклюзійно-артикуляційними порушеннями, зі звичними вивихами і підвивихами, зі шкідливими звичками, з великими навантаженнями під час занять атлетичними видами спорту [19, 21]. Важливість травми як етіологічного фактора підкреслюють в своїх роботах В. М. Трезубов і співавт. [19]. Під дисорункцією СНЩС мають на увазі цілий ряд станів, які зачіпають м'язи голови і шиї, СНЩС, черепно-мозкові нерви і ганглії [3].

Найбільш характерними проявами дисфункції СНЩС є: порушення руху нижньої щелепи, стомлюваність і відчуття дискомфрорту по ходу жувальних м'язів, гіпермобільність суглобів або обмеження відкривання рота, затруднення під час відкушування і пережовування їжі, біль, шумові явища в області суглобів під час руху нижньої щелепи (в різні моменти) у вигляді клацань, хрускоту $[10,13,37,39]$. Больові відчуття при дисфункціях пов'язані 3 порушенням тонусу м'язів (міогенний характер); зі зміщенням суглобової головки назад, де вона травмує судинно-нервове сплетіння, розташоване позаду внутрішньосуглобового диска (артрогенний характер болю); або з поєднанням перелічених чинників.

Велику увагу в адаптації до болю приділяють психологічним оракторам, таким, як різноманіття психологічних і поведінкових характеристик, включаючи стрес, неспокій і депресію [35]. Шумові явища в зчленуваннях виникають під час порушення взаємного розташування суглобового диска і суглобової головки на різних фразах руху нижньої щелепи. Кожен з цих симптомів може зустрічатися як ізольовано, так і в різних 
їх комбінаціях. В. М. Трезубов [19] у своїй роботі зазначав, що розлади функції СНЩС пов'язані не тільки, а точніше не стільки 3 оклюзійними, просторовими і нейром'язовими порушеннями, скільки з психічними травмами і психохарактерологічними особливостями особистості хворих.

Захворюванням СНЩС у віковому аспекті присвячені роботи багатьох дослідників [7,20]. Причиною дисфункції СНЩС може стати неправильно проведене ортодонтичне лікування. У вітчизняній і зарубіжній літературі більшість досліджень присвячено вивченню патології СНЩС у дітей і підлітків з порушенням оклюзії, що знаходяться на ортодонтичному лікуванні [6]. У той же час фрункціональні захворювання СНЩС спостерігаються у дітей будь-якого віку нерідко при нормальному співвідношенні зубних рядів, найбільш часто виявляються після звичного вивиху або підвивиху суглобової головки [32]. У підлітковому періоді має місце вікова диспропорція зростання опорно-рухового апарату, коли зростання кісток випереджає функціональну адаптацію м'язів і зв'язкового апарату. У підлітків у період інтенсивного росту нижньої щелепи суглобова капсула і зв'язковий апарат скронево-нижньощелепного суглоба приходить у стан перенапруження, коли навіть фрізіологічне фрункціональне навантаження на суглоб виявляється надмірним і може привести до дістензійного звичного вивиху або підвивиху суглоба. Неприродньо великий розмах рухів у суглобі викликає підвищене механічне навантаження на суглоб i сприяє розвитку запально-дистрофрічних процесів у ньому [12].

\section{Література}

1. Баданин В. В. Диагностика и ортопедическое лечение при заболеваниях ВНЧС. / В. В. Баданин, И. Ю. Лебеденко, Т. В. Морозова // Стоматология для всех. - 2000. - № 2. - С. 8-12.

2. Безруков В. М. Заболевание височно-нижнечелюстного сустава: учебное пособие для студентов медицинских вузов / В. М. Безруков. ГЭОТАР-мед., 2002. - 48 с.

3. Бугровецкая О. Г. Функциональная анатомия и биомеханика височно-нижнечелюстного сустава. Патобиомеханические изменения при дисфункции и их лечение методами мануальной терапии / О. Г. Бугровецкая, В. В. Юров, А. М. Василенко, Д. Е. Мохов, О. А. Стецюра. - М.: Медпрактика, 2006. - 92 с.

4. Гогиберидзе О. Т. Височно-нижнечелюстной сустав до и после хирургического лечения больных с верхней микро- или ретрогнатией и нижней макро- и прогнатией / О. Т. Гогиберидзе, Н. А. Рабухина, В. И. Гунько // Стоматология. - 1999. - № 78(6). - С. 28-30.

5. Дергилев А. П. Алгоритм лучевой диагностики заболеваний и повреждений височно-нижнечеслюстного сустава: тр. VII Всерос. съезда стоматологов / А. П. Дергилев, П. Г. Сысолятин, А. А. Ильин. - М., 2001. - C. 161-163.

6. Джанахара С. Нарушение функции височно-нижнечеслюстного сустава у пациентов с дистальной окклюзией (клинико-лабораторное исследование): дис. ... - М., 2003. - 178 с.
Захворювання СНЩС $є$ поширеною патологією щелепно-лицевої ділянки, яка по частоті займає третє місце після карієсу і захворювання пародонта. За даними ряду авторів частота ураження скронево-нижньощелепного суглоба у дітей та підлітків становить від 27,5 до $70 \%$ [20], у дорослих - від 40 до $70 \%$ [4]. Обстеження спортсменів-легкоатлетів у роботі І. В. Москаленко та П. О. Москаленко показало, що частота змін у компонентах СНЩС у вигляді внутрішніх порушень становить $68 \%$ : із них гіпермобільність суглоба - 64,7 \%, підвивих суглобової головки - 11,8 \%, порушення прикусу - 23,5 \% [9]. Отримані дослідниками показники значно вищі за показники під час звернення хворих з цією патологією до лікувальних установ. Це $\epsilon$ свідченням того, що фрункціональні порушення СНЩС у спортсменів реєструються частіше.

Таким чином, частота виявлення функціональних порушень СНЩС у населення, зокрема у спортсменів, висока. Ймовірною причиною цих порушень $€$ розвиток патології прикусу внаслідок значного фрізичного навантаження на кістки і м'язи голови та шиї.

Перспективою подальших досліджень $€$ вивчення частоти, етіології та патогенезу порушень СНЩС в таких специфрічних видах спорту, як бокс, східні єдиноборства, тощо.

Як практичні рекомендації під час медичного супроводу спортсменів доцільно було б проводити діагностику порушень СНЩС та своєчасно вживати заходів щодо їх корекції.

\section{Reference}

1. Баданин ВВ, Лебеденко ИЮ, Морозова ТВ. Диагностика и ортопедическое лечение при заболеваниях височно-нижнечелюстного сустава [Diagnosis and orthopedic treatment of diseases of the temporomandibular joint]. Стоматология для всех. 2000;2:8-12.

2. Безруков ВМ. Заболевание височно-нижнечелюстного сустава: учебное пособие для студентов медицинских вузов [Temporomandibular joint disease: a manual for medical students]. ГЭОТАР-мед.; 2002. 48 c.

3. Бугровецкая ОГ, Юров ВВ, Василенко АМ, Мохов ДЕ, Стецюра ОА. Функциональная анатомия и биомеханика височно-нижнечелюстного сустава. Патобиомеханические изменения при дисфункции и их лечение методами мануальной терапии [Functional anatomy and biomechanics of the temporomandibular joint. Pathobiomechanical changes in dysfunction and their treatment with manual therapy methods]. М.: Медпрактика; 2006. 92 c.

4. Гогиберидзе ОТ, Рабухина НА, Гунько ВИ. Височно-нижнечелюстной сустав до и после хирургического лечения больных с верхней микpo- или ретрогнатией и нижней макро- и прогнатией [Temporomandibular joint before and after surgical treatment of patients with upper microor retrognatia and lower macro- and prognathy]. Стоматология. 1999;78(6):28-30.

5. Дергилев АП, Сысолятин ПГ, Ильин АА. Алгоритм лучевой диагностики заболеваний и повреждений ВНЧС: труды VII Bсеросс. съезда стоматологов.М;2001:161-3. 
7. Дзараев Ч. Р. Состояние функции височно-нижнечелюстных суставов при различных аномалиях окклюзии у детей 7-15 лет: дис. ... M., 2005. $-152 \mathrm{c}$.

8. Климова Т. В. Закономерности движения нижней челюсти у детей и подростков / Т. В. Климова, Н. В. Набиев, Л. С. Персии // Ортодонтия, 2009. - № 4(48). - С. 10-14.

9. Москаленко І. В. Поширеність внутрішніх порушень СНЩС у спортстменів-легкоатлетів: зб. матеріали всеукраїнської наук.-практ. конф. з міжнародною участю «Актуальні проблеми медичного забезпечення спорту високих досягнень», 7-8 лист. 2018 р. - Суми: СумДУ, 2018. - С. 37-38.

10. Муравьева Н. С. Современные возможности электронной аксиографии в диагностике текущего состояния височно-нижнечелюстного сустава 190 (ВНЧС): сборник трудов V Всерос. науч.-практ. конф. «Образование, наука и практика в стоматологии», 12-15 февр. 2008 г. - М: Москов. мед. ун-т, 2008. - С. 205.

11. Набиев Н. В. Электромиография - современный метод диагностики функкционального состояния мышц челюстно-лицевой области / Н. В. Набиев, Т. В. Климова, Л. С. Персии, Н.В.Панкратова // Ортодонтия. - 2009. - № 2(46). - С. 13-19.

12. Омельчук М. А., редактор. Ортодонтія: підручник для студентів вищих медичних навчальних закладів. Вінниця: Нова книга, 2007. C. $28-42$.

13. Петров Б. А. Возрастные и индивидуальные особенности костномышечных структур глубокой области лица и их использование в стоматологии: дисс. / Б. А. Петров. - М., 2009. - 163 с.

14. Петросов Ю. А. Заболевания височно-нижнечелюстного сустава / Ю. А. Петросов, О. Ю. Калпакьянц, Н. Ю. Сеферян. - Краснодар: Сов. Кубань, 1996. - 352 с.

15. Семенченко Г. И. Лечение деформаций челюстей, обусловленных врожденной расщелиной верхней губы и неба / Г. И. Семенченко // Вестник хирургии и стоматологии. - 1995. - № 1. - С. 33-34.

16. Семкин В. А. Дисфункция височно-нижнечелюстного сустава / В. А. Семкин, Н. А. Рабухина. - М.: Медпрактика, 2000. - С. 15-17.

17. Слесарев О. В. Прицельная линейная томография височнонижнечелюстного сустава / О. В. Слесарев, Н. Ф. Поляруш // Маэстро стоматологии. - 2002. - № 6. - С. 39-44.

18. Сысолятин П. Г. Актуальные вопросы диагностики и лечения повреждения ВНЧС / П. Г. Сысолятин, И. А. Арсенова // Стоматология. 1999. - № 78(2). - С. 34-39.

19. Трезубов В. Н. Роль биологически адаптивной обратной связи в комплексном патогенетическом лечении заболеваний ВНЧС и жевательных мышц / В. Н. Трезубов, Е. А. Булычева, Ю. А. Быстрова, В. В. Горбачев // Вестн. стоматологии. - 2003. - № 3. - С. 33-35.

20. Фабелинская И. В. Возрастные анатомические и функциональные особенности височно-нижнечелюстного сустава у детей и подростков с врожденной расщелиной верхней губы и неба: дис. / И. В. Фабелинская. - М., 2005. - 192 с.

21. Хватов И. Л. Диагностика диссфункции ВНЧС на основании графической регистрации движений нижней челюсти: дис. / И. Л. Хватов. - М., 2001. - 141 c.

22. Badel T. Occlusion in patients with temporomandibular joint anterior: disk displacement / T. Badel // Acta. Clin. Croat. - 2008. - № 47(3). P. $129-136$

23. Barriere $P$. Massage of the lateral pterygoid muscle in acute TMJ'dysfunction; syndrome / P. Barriere, S. Zink, S. Riehm, J. L. Kahn // Rev. Stomatol. Chir, Maxilloiac. - 2009. - N 110(2). - P. 77-80. [франц.]

24. Buescher J. J. Temporomandibular joint disorders / J. J. Buescher // Am. Fam. Physician. - 2007. - N 76(10). - P. 1477-1482.

25. Burgos $E$. Antinociceptive effect of the cannabinoid agonist. WIN $55,212-2$, in the orofacial and temporomandibular formalin tests / E. Burgos, D. Pascual, M. Isabel Martin, C. Goicoechea // Eur. J. Pain. 2009. Vol. 20(2). - P. 72-74.

26. Capurso U. Orthodontic treatment of TMJ disc displacement with pain: an 18 year follow-up / U. Capurso, I. Marini // Prog. Orthod. - 2007. Vol. 8(2)2. - P. 240-250.
6. Джанахара С. Нарушение функции ВНЧС у пациентов с дистальной окклюзией (Клинико-лабораторное исследование) [Dysfunction of the TMJ in patients with distal occlusion (Clinical and laboratory research)] [диссертация]. Москва; 2003. 178 c.

7. Дзараев ЧР. Состояние функции височно-нижнечелюстных суставов при различных аномалиях окклюзии у детей 7-15 лет [The state of the function of the temporomandibular joints in various anomalies of occlusion in children aged 7-15 years old] [диссертация]. Москва; 2005. $152 \mathrm{c}$.

8. Климова ТВ, Набиев НВ, Персии ЛС. Закономерности движения нижней челюсти у детей и подростков [Patterns of the lower jaw ьщмуьуте in children and adolescents ]. Ортодонтия. 2009;4(48):10-4.

9. Москаленко IB, Москаленко ПО. Поширеність внутрішніх порушень СНЩС у спортстменів-легкоатлетів. Матер. всеукр. наук.-практ. конфр. $з$ міжнар. участю «Актуальні проблеми медичного забезпечення спорту високих досягнень». Суми; 7-8 лист. 2018; 2018.37-8.

10. Муравьева НС. Современные возможности электронной аксиографии в диагностике текущего состояния височно-нижнечелюстного сустава 190 (ВНЧС). Сборник трудов V Всерос. науч.-практ. конф. «Образование, наука и практика в стоматологии»; 12-15 февр. 2008; М: Московский мед. ун-т; 2008.205.

11. Набиев НВ, Климова ТВ, Персии ЛС, Панкратова НВ. Электромиография - современный метод диагностики функционального состояния мышц челюстно-лицевой области [Electromyography - a modern method of diagnosing the functional state of the muscles of the maxillofacial region]. Ортодонтия. 2009;2(46):13-9.

12. Омельчук МА, редактор. Ортодонтія. Вінниця: Нова книга; 2007.28-42

13. Петров БА. Возрастные и индивидуальные особенности костномышечных структур глубокой области лица и их использование в стоматологии [Age-related and individual characteristics of the bone-muscular structures of the deep facial area and their use in dentistry] [диссертация]. Москва; 2009. 163 с.

14. Петросов ЮА, Калпакьянц ОЮ, Сеферян НЮ. Заболевания височно-нижнечелюстного сустава [Temporomandibular joint diseases]. Краснодар: Советская Кубань; 1996. 352 с.

15. Семенченко ГИ. Лечение деформаций челюстей, обусловленных врожденной расщелиной верхней губы и неба [Treatment of jaw deformities due to congenital cleft lip and palate]. Вестник хирургии и стоматологии. 1995; 1:33-4.

16. Семкин ВА, Рабухина НА. Дисфункция височно-нижнечелюстного сустава [Temporomandibular joint dysfunction]. Москва: Медпрактика; 2000. 15-7.

17. Слесарев ОВ, Поляруш НФ. Прицельная линейная томография ВНЧС [TMJ targeted linear tomography]. Маэстро стоматологии. 2002:6:39-44.

18. Сысолятин ПГ, Арсенова ИА. Актуальные вопросы диагностики и лечения повреждения височно-нижнечелюстного сустава [Actual issues of diagnosis and treatment of the temporomandibular joint damage]. Стоматология. 1999;78(2):34-9.

19. Трезубов ВН, Булычева ЕА, Быстрова ЮА, Горбачев ВВ. Роль биологически адаптивной обратной связи в комплексном патогенетическом лечении заболеваний ВНЧС и жевательных мышц [The role of biologically adaptive feedback in the complex pathogenetic treatment of TMJ and masticatory muscles diseases]. Вестник стоматологии. 2003:3:33-5.

20. Фабелинская ИВ. Возрастные анатомические и функциональные особенности височно-нижнечелюстного сустава у детей и подростков с врожденной расщелиной верхней губы и неба [Age-related anatomical and functional features of the temporomandibular joint in children and adolescents with congenital cleft of upper lip and palate] [диссертация]. Москва; 2005. 192 c.

21. Хватов ИЛ. Диагностика дисфуункции височно-нижнечелюстного сустава на основании графической регистрации движений нижней челюсти [Diagnosis of the dysfunction of the temporomandibular joint based on graphic registration of movements of the lower jaw] [диссертация]. Москва; 2001. 141 с. 
27. Carini F. Human temporomandibular joint morphogenesis / F. Carini, G. A. Scardina, C. Caradonna, P. Messina, V. Valenza // Ital J. Anat. Embryol. - 2007. - Vol. 112(4). - P. 267-275.

28. Carlson C. R. Psychological considerations for chronic orofacial pain / C. R. Carlson // Oral Maxillofac. Surg. Clin. North Am. - 2008. Vol. 20(2). - P. 185-195.

29. Cascarini L. Bilateral TMJ dislocation in a 23-month-old infant: a case report / L. Cascarini, M. G. Cameron // Dent. Update. - 2009. Vol. 36(5). - P. 312-313.

30. Coskun Akar $G$. Examination of the heads of the lateral pterygoid muscle on the temporomandibular joint / G. Coskun Akar, F. Govsa, Z. Ozgur // J. Craniofac. Surg. 2009. - Vol. 20(1). - P. 219-223.

31. Christiansen E. X. Computed tomography of the normal temporomandibular joint / E. X. Christiansen, T. T. Chan, J. R. Tompson, A. N. Hasso, D. B. Hinshaw, S. Kopp // Scand-J-Dent-Res. - 1987. - Vol. 95(6). - P. 499509.

32. Ember E. A. TMJ diszfunkcion czindroma epidemiologiai vizsgalata / E. A. Ember // Forogv. Szemle. - 1986. - Vol. 79(12). - P. 355-359.

33. Fiorentino P. M. Temporomandibular joint disorders during MTV infection: a case report / P. M. Fiorentino, M.Gi. Piancino, G. Debernardi, N. Attard // J. Orofac. Pain. - 2009. - Vol. 23(2). - P. 174-176.

34. List T. TMD in children and adolescents: prevalence of pain, gender differences, and perceived treatment need / T. List, K. Wahlund, B. Wenneberg, S. F. Dworkin // J. Orofac. Pain. - 1999. - Vol. 13(1). - P. 9-20.

35. Minden K. Long-term outcome in patients with juvenile idiopathic arthritis / K. Minden, M. Niewerth, J. Listing // Arthr. Rheum. - 2002. Vol. 46(2). - P. 2392-2401.

36. Movahed R. Protocol for concomitant Temporomandibular Joint Custom-Fitted Total Joint Reconstruction and Orthognathic Surgery Using Computer-Assisted Surgical Simulation / R. Movahed, L. M. Wolford // Oral and Maxillofacial Surgery Clinics of North America. - 2015. - Vol. 27(1). P. 37-46.

37. Murdock B. TMJ replacement: A New Zealand perspective / B. Murdock, J. Buchanan, J. Cliff // Int. J. Oral Maxillofac Surg. - 2014. - Vol. 43. P. 595-599.

38. Goncalves J. R. Airway Space Changes after Maxillomandibular Counterclockwise Rotation and Mandibular Advancement with TMJ Concepts Total Joint Prostheses: Three-Dimensional Assessment / J. R. Goncalves, LCR Gomes, A.P. Vianna, D. B. Rodrigues, DAG Concalves, L.W. Wolford // Int. J. Oral Maxillofac Surg. - 2013. - Vol. 42. - P. 1014-1022. 39. Ravelli A. Early predictors of outcome in JIA / A. Ravelli, A. Martini // Clin. and Exp. Rheumatol. - 2003. - Vol. 21(31). - P. 89-93.

40. Saito E. T. Global body posture evaluation in patients with temporomandibular joint disorder / E. T. Saito, P. M. Akashi, C. Sacco // Clinics. 2009. - Vol. 64(1). - P. 35-39.
22. Badel T. Occlusion in patients with temporomandibular joint anterior: disk displacement. Acta. Clin. Croat. 2008;47(3):129-36.

23. Barriere P, Zink S, Riehm S, Kahn JL., Massage of the lateral pterygoid muscle in acute TMJ'dysfunction; syndrome. Rev. Stomatol. Chir, Maxilloiac. 2009;110(2):77-80.

24. Buescher JJ. Temporomandibular joint disorders. Am. Fam. Physician. 2007;76(10):1477-82.

25. Burgos E, Pascual D, Isabel Martin M, Goicoechea C. Antinociceptive effect of the cannabinoid agonist, WIN 55,212-2, in the orofacial and temporomandibular formalin tests. Eur. J. Pain. 2009;20(2):72-4.

26. Capurso U, Marini I. Orthodontic treatment of TMJ disc displacement with pain: an 18 year follow-up. Prog. Orthod. 2007;8(2 )2:240-50.

27. Carini F, Scardina GA, Caradonna C, Messina P, Valenza V. Human temporomandibular joint morphogenesis. Ital J. Anat. Embryol. 2007;112(4):267-75.

28. Carlson CR. Psychological considerations for chronic orofacial pain. Oral Maxillofac. Surg. Clin. North Am. 2008;20(2):185-95.

29. Cascarini L, Cameron MG. Bilateral TMJ dislocation in a 23-monthold infant: a case report. Dent. Update. 2009;36(5):312-13.

30. Coskun Akar G, Govsa F, Ozgur Z. Examination of the heads of the lateral pterygoid muscle on the temporomandibular joint. J. Craniofac. Surg. 2009;20(1):219-23.

31. Christiansen EX., Chan TT, Tompson JR, Hasso AN, Hinshaw DB, Kopp S. Computed tomography of the normal temporomandibular joint. Scand-J-Dent-Res. 1987;95(6):499-509.

32. Ember EA TMJ diszfunkcion czindroma epidemiologiai vizsgalata. Forogv. Szemle. 1986;79(12):355-9.

33. Fiorentino PM, Piancino MGi, Debernardi G, Attard N. Temporomandibular joint disorders during MTV infection: a case report. J. Orofac. Pain. 2009;23(2):174-6.

34. List T, Wahlund K, Wenneberg B, Dworkin SF. TMD in children and adolescents: prevalence of pain, gender differences, and perceived treatment need. J. Orofac. Pain. 1999;13(1):9-20.

35. Minden K, Niewerth M, Listing J. Long-term outcome in patients with juvenile idiopathic arthritis. Arthr. Rheum. 2002;46(2):2392-2401.

36. Movahed R, Wolford LM: Protocol for concomitant Temporomandibular Joint Custom-Fitted Total Joint Reconstruction and Orthognathic Surgery Using Computer-Assisted Surgical Simulation. Oral and Maxillofacial Surgery Clinics of North America. 2015;27(1):37-46.

37. Murdock B, Buchanan J, Cliff J: TMJ replacement: A New Zealand perspective. Int. J. Oral Maxillofac Surg. 2014;43:595-9.

38. Goncalves JR, Gomes LCR, Vianna AP, Rodrigues DB, Concalves DAG, Wolford LW: Airway Space Changes after Maxillomandibular Counterclockwise Rotation and Mandibular Advancement with TMJ Concepts Total Joint Prostheses: Three-Dimensional Assessment. Int. J. Oral Maxillofac Surg. 2013;42:1014-22.

39. Ravelli A, Martini A. Early predictors of outcome in JIA. Clin, and Exp. Rheumatol. 2003;21(31):89-93.

40. Saito ET, Akashi PM, Sacco C. Global body posture evaluation in patients with temporomandibular joint disorder. Clinics. 2009;64(1):35-9. 